\title{
Rada Europejska w procesie przeksztalceń strukturalnych 1961-1977
}

\section{Wprowadzenie}

Nazwa Rada Europejska, po raz pierwszy, została użyta oficjalnie podczas spotkania szefów państw i szefów rządów EWG 10 grudnia 1974 roku w Paryżu. Postanowiono podczas niego, że takie szczyty będą odbywać się regularnie, co najmniej dwa razy w roku na najwyższym szczeblu politycznym. Szefom rządów lub głowom państw towarzyszyć mieli ministrowie spraw zagranicznych. Z oficjalną propozycją utworzenia tego kolejnego organu aparatu instytucjonalnego ewoluujących Wspólnot oficjalnie wystąpił Valery Giscard d'Estaign. Funkcje Rady Europejskiej po raz pierwszy sformułowano dopiero w Deklaracji z Londynu w czerwcu 1977 r. Jednakże idea, która przyświecała organizacji tego typu spotkań narodziła się dużo wcześniej. Spotkania tego typu odbywały się już w latach 60. z inicjatywy Charlesa de Gaulle'a. Pierwsze postępy w procesie integracji europejskiej wymagały spotkań nieformalnych dających możliwość swobodnego dialogu, mającemu przyczynić się do inicjowania nowych rozwiązań na rzecz współpracy, jak i rozwiązywania problemów. Instytucja ta rozwijała się wraz z tworzeniem mechanizmów współpracy politycznej WE.

Podstawową zasadą funkcjonowania kształtującej się Europejskiej Wspólnoty Gospodarczej było oparcie jej działania na permanentnym procesie interakcji pomiędzy podmiotami instytucjonalnymi i państwami członkowskimi zaangażowanymi w proces decyzyjny. Zwornikiem tego procesu stał się tworzony system instytucjonalny. Kluczową rolę w tym systemie zajmowały spotkania szefów rządów i głów państw, które stopniowo przekształciły się w instytucję będącą centrum decyzji politycznej. Zakres formalnych i nieformalnych uprawnień Rady Europejskiej stale się zwiększał. Kolejne postanowienia polityczne i wprowadzane prawne regulacje wyznaczały znaczące etapy tego procesu, ponieważ określały jej rolę i wiodącą funkcję w EWG. Artykuł odnosi się do źródeł i przejawów dynamiki instytucjonalnej w procesie kształtowania europejskiej współpracy politycznej w okresie 1961-1975. Jego celem jest analiza czynników warunkujących pierwszy etap rozwoju Rady Europejskiej w świetle przyjmowanych decyzji politycznych, a także praktyki jej działań. Narastanie współzależności w kształtowanych relacjach między państwami w sytu-

${ }^{1}$ Artykuł został przygotowany w ramach projektu finansowanego przez Narodowe Centrum Nauki: „Rada Europejska w procesie kształtowania kompetencji formalnych i nieformalnych w zakresie działań zewnętrznych Unii Europejskiej”, nr 2015/19/B/HS5/00131. 
acji potrzeby i konieczności współpracy zbiega się z procesem zmian w odniesieniu do konieczności kształtowania nowych funkcji instytucji. To znacząco wpłynęło na dynamikę międzyinstytucjonalnych przekształceń. Określając determinanty wpływające na te przekształcenia, podkreślić należy dysfunkcjonalność systemu, a także jego ograniczenia.

\section{Geneza organizacji szczytów przywódców państw}

W Paryżu, 10 lutego 1961 r., rozpoczęło się pierwsze spotkanie na szczycie przywódców państw i rządów, na którym wyrażono chęć zacieśnienia współpracy politycznej. W komunikacie po szczycie wskazano, że „dotyczy to stworzenia unii, która będzie się progresywnie rozwijać... Ta unia ograniczona w tym momencie do państw EWG będzie się w przyszłości rozszerzać" (Communique..., 1961). Tematyka spotkania wykraczała poza ramy objęte traktatami założycielskimi trzech wspólnot. Podczas obrad poruszano między innymi kwestie tworzenia ram współdziałania $\mathrm{w}$ relacjach z państwami trzecimi. Inicjatorem większości propozycji tworzenia ram współpracy politycznej była delegacja francuska. To nieformalne spotkanie przywódców europejskich wspólnot było początkiem drogi prowadzącej do instytucjonalizacji działań na płaszczyźnie politycznej, które przerodziły się w przyszłości w ramy Rady Europejskiej.

Na kolejnym szczycie szefów państw i rządów, 18 lipca 1961 roku w Bonn, sześciu przywódców kontynuowało rozmowy w celu zacieśnienia więzi politycznych. W deklaracji przygotowanej podczas szczytu wyrażono chęć przeprowadzania regularnych spotkań służących wymianie poglądów, koordynacji polityki i wypracowania wspólnych stanowisk w celu jedności politycznej Europy. W konsekwencji wstępnych uzgodnień poczynionych podczas obrad powołano komisję międzyrządową pod przewodnictwem Christiana Foucheta ${ }^{2}$, która miała przedstawić propozycję podjęcia działań w obszarze europejskiej współpracy politycznej. Stanowisko wyrażone w tzw. planie Foucheta I i planie Foucheta II dotyczyło projektu traktatu ustanawiającego europejską unię polityczną (Témoignage..., 1972).

Pierwsza francuska propozycja, plan Foucheta I, przedłożona została 19 października oraz 2 listopada 1961 roku, podczas spotkań szefów rządów i ministrów spraw zagranicznych państw Europejskiej Wspólnoty Gospodarczej. W dokumencie przygotowano ramy ustanowienia „unii”, której celami byłoby: zapewnienie przyjęcia wspólnej polityki zagranicznej; zagwarantowanie ścisłej współpracy między państwami w dziedzinie nauki i kultury, co pozwoli na rozwój wspólnego dziedzic-

${ }^{2}$ Christian Fouchet (1911-1974) to francuski dyplomata, polityk, mąż stanu. Sprawował funkcję ministra kilku resortów w pierwszym i drugim składzie rządu Pierre'a Mendès France w latach 1954-1955 oraz w drugim, trzecim i czwartym składzie rządu Georges’a Pompidou w latach 19621968. W okresie 1958-1962 pełnił funkcję ambasadora w Danii. Był on pierwszym przedstawicielem francuskiego rządu przy Polskim Komitecie Wyzwolenia Narodowego. Dziesięć lat po porażce swego planu, Ch. Fouchet wyrażając uznanie polityce generała Ch. de Gaulle'a, przedstawił przyczyny, które doprowadziły do niepowodzenia unii politycznej w Europie, wskazując rząd belgijski i holenderski za winnych niepowodzenia. 
twa i ochronę wartości cywilizacji; przyczynienie się do ochrony praw człowieka, demokracji i wolności; wzmocnienie, we współpracy z innymi narodami bezpieczeństwa poprzez ustanowienie wspólnej polityki obrony (Projet de traité, Plan Fouchet I, 1961, art. 2). Instytucjami przyszłej Unii miały zostać Rada, Zgromadzenie Parlamentarne i Europejska Komisja Polityczna. Zgodnie z projektem, Radę mieli tworzyć przedstawiciele $\mathrm{w}$ randze szefów państw lub rządów. Jej spotkania miały mieć miejsce raz na cztery miesiące. Między spotkaniami, przynajmniej raz, miało zostać przeprowadzone spotkanie ministrów spraw zagranicznych. Zaproponowano także możliwość przeprowadzenia spotkań nadzwyczajnych, na tych dwóch szczeblach, na żądanie jednego lub kilku państw. Na każde ze spotkań na szczeblu szefów państw lub rządów, Rada miała wybrać przewodniczącego, który sprawowałby funkcję w okresie od dwóch miesięcy przed spotkaniem do dwóch miesięcy po spotkaniu. Sprawowałby on także swoją funkcję podczas szczytów nadzwyczajnych. Spotkaniom ministerialnym miał przewodniczyć minister spraw zagranicznych państwa, które miało przewodniczącego na wyższym szczeblu szefów państw lub rządów. Rada miała podejmować decyzję jednomyślnie. Nieobecność jednego lub dwóch państw nie stanowiłaby przeszkody w podjęciu decyzji. Każde z państw nieobecnych mogłoby później przystąpić do decyzji. Ciekawą była propozycja podziału kosztów utrzymania przyszłej unii politycznej. Państwa podzieliły się kosztami utrzymania nowych form współpracy, według przyjętego klucza, w sposób następujący: Belgia 7,9\%, Francja 28\%, Luksemburg 0,2\%, Holandia 7,9\%, Niemcy $28 \%$, Włochy $28 \%$.

Zadaniem grupy Foucheta było opracowanie projektu umowy o ustanowieniu unii politycznej w Europie Zachodniej. Propozycja nawiązywała do wcześniejszej koncepcji Europejskiej Wspólnoty Politycznej. W ramach ustanowionej unii miała być prowadzona wspólna polityka zagraniczna w formule międzyrządowej oraz polityka obronna we współpracy z innymi narodami (Bussière, Willaert, 2010). Proponowana unia nie miała dotyczyć wymiaru gospodarczego współpracy, z wyłączeniem wybranych kwestii w obszarze nauki i kultury. Taktyka negocjacyjna Francji zawiodła. Propozycja nie spotkała się z akceptacją pozostałych państw. Wpływ na to miały późniejsze francuskie zmiany projektu. Belgia i Holandia, krytycznie podeszły do proponowanych przez Charlesa de Gaulle'a poprawek rozszerzających współpracę o wymiar gospodarczy, jak i francuskiego sprzeciwu wobec rozszerzenia wspólnot o Wielką Brytanię. Kwestia członkostwa Wielkiej Brytanii we wspólnotach stała się podłożem ostrego sporu, który dobitnie podsumował Paul Henri Spaak mówiąc ,jeżeli nie chcecie integracji, trzeba nam Wielkiej Brytanii; jeżeli nie chcecie Wielkiej Brytanii, trzeba nam integracji. Trzeba nam jednego lub drugiego" (Soutou, 1992). Do przeciwników propozycji francuskich, broniąc wpływu NATO na politykę bezpieczeństwa europejskiego, przyłączyły się Włochy. Realizacja planu stała się niemożliwa. Poprawiona wersja projektu przedstawiona 13 stycznia 1962 roku nie spotkała się z aprobatą Charlesa de Gaulle'a, który anulował kompromis.

18 stycznia 1962 roku w Paryżu, podczas spotkania szefów rządów i ministrów spraw zagranicznych państw Europejskiej Wspólnoty Gospodarczej, Francja przedstawiła kolejną propozycję zwaną jako plan Foucheta II. Druga propozycja zakładała 
utworzenie unii politycznej, której celem było koordynowanie i stopniowe unifikowanie polityki państw w obszarze wspólnego interesu polityki zagranicznej, gospodarki, kultury i obrony (Projet de traité, Plan Fouchet II, 1962). Unii miała być przyznana osobowość prawna. Jej organami miały zostać Rada, Komitet Ministrów, Komisja Polityczna, Europejskie Zgromadzenie Parlamentarne. Rada, podobnie jak we wcześniejszym planie miała składać się z szefów rządów i państw spotykających się co cztery miesiące, przynajmniej trzy razy w roku (Blaes, 1971). Projekt ten był kontynuacją wizji „Europy Ojczyzn” promowanej przez Francję. Ostatecznie, druga propozycja, po modyfikacjach, także została odrzucona przez europejskich partnerów 17 kwietnia 1962 roku. Wpływ na fiasko koncepcji unii politycznej miały głównie trzy czynniki: proponowana struktura instytucjonalna, orientacja na wzmocnienie NATO w systemie bezpieczeństwa europejskiego, członkostwo Wielkiej Brytanii we wspólnotach. W poprawionej wersji planu Foucheta II (trzeciej propozycji) rozszerzono zakres celów politycznych Unii o płaszczyznę gospodarczą współpracy, co łączy działanie planowanej Unii z dotychczasowymi działaniami wspólnotowymi. W art. 17 znajduje się zapis „szanując strukturę przewidzianą traktatami paryskimi i rzymskimi powołującymi wspólnoty europejskie". Powyższe dylematy dotyczące zapisów na temat kształtu ram instytucjonalnych były esencją sporu o koncepcję określającą przyszłość politycznej integracji europejskiej.

Pomimo porażki koncepcji generała Charlesa de Gaulle’a wyrażonej w projekcie unii politycznej, warte odnotowania jest małe zwycięstwo na polu współpracy niemiecko-francuskiej, które dało owoce w latach późniejszych. 22 stycznia 1963 roku podpisano traktat elizejski, francusko-niemiecką umowę dotyczącą współpracy politycznej i wojskowej, a także uwzględniającą edukację młodzieży. K. Popowicz stwierdza, że podpisanie traktatu było datą graniczną i oznaczało koniec roli de Gaulle’a w dziele umacniania europejskiej jedności. Od 1963 r. do zakończenia swojej prezydentury stał się on głównym hamulcowym procesu integracji (Popowicz, 2006, s. 78-79). Koniec lat 60. przynosi zmiany w podejściu do dalszej współpracy w tandemie francusko-niemieckim. Wpływ na to mają głównie dwa czynniki. Pierwszy, to usamodzielnienie się Niemiec na arenie międzynarodowej, w szczególności nowa ostpolitik Willy Brandta, która nie korzystała z pośrednictwa francuskiego w rozmowach z ZSRR. Drugi, to coraz większa dysproporcja we wzroście gospodarczym związana z kryzysem finansów Francji przy jednoczesnej prospericie gospodarki niemieckiej. Motorem europejskiej integracji politycznej stał się tandem francusko-niemiecki. Rozłam wizji politycznej swoje źródło miał na podłożu gospodarczym. Lata sześćdziesiąte przesądziły o zmianie kształtu przywództwa politycznego w Europie.

Trudno jednoznacznie określić źródło porażki koncepcji tworzenia ram współpracy politycznej. Lata sześćdziesiąte zdominowane były częstym brakiem zgody politycznej, co negatywnie wpływało na próby instytucjonalnego zacieśnienia współpracy. Następujące po sobie, nieprzyjęcie planów Foucheta, brak porozumienia w sprawie rozszerzenia, kryzys pustego krzesła, stały się symbolami bezradności europejskiej, której głównym podłożem był spór o realne przywództwo polityczne. Obawa, że oś francusko-niemiecka zdominuje politykę europejską, była duża. Konsekwencją powyższych niepowodzeń była kilkuletnia przerwa w organizacji spotkań szefów rządów i państw do maja 1967 roku (patrz tabela 1). 
Spotkania na szczycie przywódców państw Wspólnot Europejskich w latach 1961-1974

\begin{tabular}{||l|l|l||}
\hline \multicolumn{1}{|c|}{ Data } & \multicolumn{1}{c||}{ Miejsce } & \multicolumn{1}{c||}{ Przewodniczący } \\
\hline 10-11 lutego 1961 & Paryż (Quai d'Orsay) & Charles de Gaulle \\
\hline 18-19 lipca 1961 & Bonn (Godesberger Redoute) & Konrad Adenauer \\
\hline 29-30 maja 1967 & Rzym (Kapitol) & Aldo Moro \\
\hline 1-2 grudnia 1969 & Haga (Ridderzaal) & Piet de Jong \\
\hline 19-21 października 1972 & Paryż (Centre des conférences internationales) & Barend Biesheuvel \\
\hline 14-15 grudnia 1973 & Kopenhaga (Bella Center) & Anker Jorgensen \\
\hline 9-10 grudnia 1974 & Paryż (Quai d'Orsay) & Valéry Giscard d'Estaing \\
\hline \hline
\end{tabular}

* Z udziałem trzech zaproszonych państw Danii, Irlandii, Wielkiej Brytanii.

Źródło: Opracowanie własne.

Obchody dziesiątej rocznicy podpisania traktatów rzymskich stanowiły moment „,nowego otwarcia” działań na rzecz współpracy politycznej (Werts, 2008, s. 9-10). To było ostatnie spotkanie przywódców europejskich, w którym uczestniczył generał Charles de Gaulle, któremu towarzyszył premier Georges Pompidou. W komunikacie po szczycie rzymskim szefowie państw lub rządów powrócili do projektu przedstawionego podczas konferencji w Bonn 18 lipca 1961 roku. Zgodzili się przeanalizować możliwość zacieśnienia politycznych więzi metodami i procedurami, które zależeć będą od doświadczeń i okoliczności (The Rome Summit..., 1967).

\section{Ku europejskiej współpracy politycznej}

Nowy prezydent Francji, Georges Pompidou, wchodząc na arenę europejską, odciął się od priorytetów swojego poprzednika. Okazją do tego stała się konferencja w Hadze zorganizowana 1-2 grudnia 1969 roku. Stanowiła ona kluczowy krok na drodze do podjęcia dalszego zaangażowania w celu stworzenia instytucjonalnej współpracy politycznej. To było pierwsze spotkanie na szczycie, w którym udział wzięli przedstawiciele Komisji. Na spotkaniu podjęto decyzję zarówno w sprawie budowy unii gospodarczo-walutowej w oparciu o założenia Planu Wernera, jak i w sprawie koordynacji wzajemnej polityki na rzecz budowy unii politycznej poprzez utworzenie w przyszłości podstaw struktury współpracy politycznej. Jednym z istotnych postanowień, które zostało podjęte na tej konferencji, była decyzja w sprawie regularnych spotkań na szczycie, które miały być poświęcone współpracy politycznej. Ważną kwestią było także określenie zmian dotyczących finansowania wspólnot z dochodów własnych. Podczas obrad otwarto drogę do pierwszego rozszerzenia wspólnot. Konferencja w Hadze przebiegała pod hasłem promowanym przez nowego prezydenta Francji „dokończenie, pogłębienie, poszerzenie” (Ludlow, 2003). To hasło silnie wpisało się w dyskurs polityczny następnych spotkań lat 70. Podczas konferencji szefowie państw członkowskich Europejskiej Wspólnoty Gospodarczej zwrócili się do ministrów spraw zagranicznych o sprawozdanie na temat możliwości stworzenia ram formalnej współpracy politycznej. 
Efektem konferencji był raport Davignona I (inaczej raport luksemburski). Nazwa raportu pochodzi od nazwiska dyplomaty belgijskiego, w latach 1959-1977 ministra spraw zagranicznych Królestwa Belgii, Étienne’a Davignona, który przewodniczył komitetowi utworzonemu przez państwa członkowskie po szczycie haskim. Komitet Davignona został zobowiązany do opracowania metody osiągnięcia unifikacji politycznej, uwzględniając planowany proces rozszerzenia. Raport przyjęty przez ministrów spraw zagranicznych wspólnot europejskich 27 października 1970 roku w Luksemburgu nakreślił ramy możliwej współpracy politycznej państw członkowskich oraz metody jej realizacji. Ustalono, iż dla realizacji celów konieczne są regularne spotkania ministrów spraw zagranicznych i spotkania Komitetu Politycznego (w składzie dyrektorów departamentów ministerstw spraw zagranicznych państw członkowskich). Uzgodniona formuła spotkań miała przyjąć formę międzyrządową. We współpracę włączone były także inne instytucje wspólnotowe, w szczególności Komisja Europejska i Parlament Europejski. Pierwsze spotkanie konsultacyjne ministrów spraw zagranicznych odbyło się 19 listopada 1970 roku w Monachium. Ustalenia dotyczące współpracy politycznej stały się początkiem zacieśniania więzi między państwami członkowskimi. Mechanizm koordynacji działań na płaszczyźnie politycznej rozpoczęto nazywać Europejską Współpracą Polityczną. Trudno jednak w tym okresie wskazać jakiekolwiek spektakularne sukcesy na arenie międzynarodowej osiągnięte za pomocą nowego mechanizmu. Proces współpracy wiązał się z koniecznością wypracowania praktyki, której podstawą były przyjęte regulacje (Czachór, 1994). Największe trudności stanowiły kwestie proceduralne. Warto zwrócić uwagę na spór o siedzibę Sekretariatu politycznego koordynującego spotkania ministrów spraw zagranicznych, który stał się symbolem ukrytych obaw państw członkowskich determinujących możliwość większego zaangażowania na rzecz budowy wspólnych celów w polityce zagranicznej. George Pompidou jako siedzibę Sekretariatu zaproponował Paryż, co spotkało się z protestem pozostałych państw, zwłaszcza Wielkiej Brytanii wchodzącej do wspólnot. Jak twierdził Fouchet porozumienie w tej sprawie było już prawie pewne, co potwierdzało odbycie wizyty, wraz z kilkoma zaproszonymi przedstawicielami pozostałych państw, w proponowanej siedzibie Sekretariatu na rogu rue de la Faisanderie i placu Bugeaud (Témoignage..., 1972). Tak silna reakcja uwidoczniła strach przed francuską dominacją na arenie europejskiej. Symboliczny brak konsensusu w sprawie siedziby Sekretariatu stanął na przeszkodzie powstania tego organu.

Pomimo drobnych niepowodzeń, podczas szczytu paryskiego dziewięciu szefów rządów i państw w 1972 roku postanowiono o rozwinięciu ram współpracy politycznej ${ }^{3}$ W spotkaniu uczestniczyli także przywódcy państw przyszłego rozszerzenia, których zaproszono do udziału na równych zasadach. W pierwszej wspólnej deklaracji po szczycie przywódcy wypowiedzieli się zarówno na temat polityki gospodarczo-monetarnej, regionalnej, społecznej, przemysłu i nauki, środowiska, energii, jak i relacji zewnętrznych, współpracy politycznej i wzmocnienia instytucjonalnego. Elementem deklaracji było zobowiązanie do przekształcenia dotychczasowych relacji między państwami w unię europejską (Déclaration du sommet de Paris, 1972). Nie określono

${ }^{3}$ Pod dużym znakiem zapytania stało to czy szczyt dojdzie do skutku. Ostatnie przeszkody usunięto podczas rozmów na linii Pompidou-Brandt $\mathrm{z}$ okazji inauguracji igrzysk olimpijskich w Monachium. 
jednak jaka miała być forma prawna przyszłej unii, jaki kierunek integracji, w oparciu o założenia której koncepcji będzie przyszła unia się tworzyć. Podczas spotkania padały ogólne zapewnienia o woli większej współpracy w sprawach polityki zagranicznej. Wytyczne szczytu uszczegółowiono rok później. Potrzeba działań na rzecz współpracy politycznej znalazła odzwierciedlenie w raporcie Davignona II (inaczej raporcie kopenhaskim), przygotowanym pod jego przewodnictwem przez Komitet Polityczny, a przyjętym przez ministrów spraw zagranicznych państw Europejskiej Wspólnoty Gospodarczej 23 lipca 1973 roku w Kopenhadze. Raport określał metody usprawnienia funkcjonowania dotychczasowej współpracy politycznej. Wyrazem wspólnej woli politycznej na rzecz budowy nowej konstrukcji europejskiej było przyjęcie Deklaracji o tożsamości europejskiej, która wprowadzała to pojęcie, także we wspólne relacje zewnętrzne (Déclaration sur l'identité européenne, 1973). W postanowieniach wskazano, że „Dziewiątka” na bazie raportów luksemburskiego i kopenhaskiego ustanowi system współpracy politycznej. Podkreślono, że „Europa 9” jest świadoma obowiązków międzynarodowych" i chce grać aktywną rolę w sprawach międzynarodowych (Déclaration sur l'identité européenne, 1973). Państwa zobowiązały się do konsultowania przed przyjęciem wspólnego stanowiska. Ustalono także podstawy współdziałania w ramach polityk skierowanych do państw trzecich. Biorąc pod uwagę zwiększenie zaangażowania państw na rzecz tworzenia nowej formy współdziałania politycznego podjęto decyzję o zwiększeniu częstotliwości spotkań na szczeblu ministerialnym do przynajmniej czterech rocznie. Utrzymano także współpracę korespondentów europejskich (oddelegowanych pracowników krajowych ministerstw spraw zagranicznych ) mających zapewnić stały kontakt niezbędny do prowadzenia wspólnych działań (Mourlon-Druol, 2014, s. 47-48).

Warto podkreślić, iż państwa zaangażowane w ramy współpracy politycznej działały poza strukturami trzech wspólnot, stanowiąc nową, nieformalną płaszczyznę współpracy. Spotkania służyły wymianie informacji i miały głównie charakter konsultacyjny. Na kolejnych szczytach przygotowywano wspólne deklaracje polityczne. Zgodna wola polityczna zainteresowanych rządów przybierała postać raportów ministrów spraw zagranicznych. Współpraca rozwijała się bez formalnej struktury instytucjonalnej, niezależnie od systemu instytucjonalnego wspólnot. Na spotkania w ramach konferencji przybywali przywódcy państw, a ich zapleczem merytorycznym byli ministrowie spraw zagranicznym. Spotkania były przygotowywane przez Komitet Polityczny (odpowiednik COREPER we WE). Komisja Wspólnot funkcjonowała głównie w charakterze obserwatora sceny politycznej. Wpływ EWP na scenę międzynarodową był bardzo ograniczony. Współpraca międzyrządowa ukazywała sprzeczne interesy państw członkowskich ${ }^{4}$. Współpraca stała się jednak płaszczyzną regularnych konsultacji w celu wypracowania wspólnego stanowiska, co owocowało pewnymi sukcesami na arenie międzynarodowej (Wessels, 2016, s. 32-36).

Przełomowym okazało się spotkanie w Paryżu 9-10 grudnia 1974 roku, gdzie szefowie państw i rządów, potwierdzając dalszą wolę współpracy politycznej i konieczność jej pogłębiania, postanowili o ściślejszej koordynacji działań w zakresie

${ }^{4}$ W latach 70. i 80., przykładem mogą być spory uniemożliwiające wypracowanie stanowiska państw w sprawach dotyczących wojny o Falklandy, inwazji Związku Radzieckiego na Afganistan, interwencji wietnamskiej w Kambodży, rozbrojenia nuklearnego, dialogu izraelsko-palestyńskiego. 
polityki zagranicznej poprzez ustalanie wspólnego stanowiska i jego wdrażanie we wszystkich obszarach polityki międzynarodowej, które dotyczą wspólnoty. Ustalono także, że spotkania będą odbywać się trzy razy w roku lub częściej, gdy okaże się to niezbędne, a przewodniczący będzie wykonywał funkcję rzecznika „dziewiątki” (Communique..., 1974). Prezydent Francji Valèry Giscard d'Estaing ponowił próby przekonania sceptycznie nastawionych przedstawicieli państw do koncepcji organizowania regularnych spotkań pod nazwą Rady Europejskiej. Drugi dzień konferencji paryskiej 10 grudnia 1974 r., podczas którego jego propozycja została zaaprobowana przez pozostałych przywódców uznaje się za umowną datę powstania Rady Europejskiej. W nowej formule jej działania miały dotyczyć zarówno działań wspólnotowych, jak i być niezbędnym impulsem do rozwoju współpracy na płaszczyźnie politycznej. Pierwsze spotkanie Rady Europejskiej rozpoczęło się w Dublinie 10 marca 1975 roku. Ziemowit J. Pietraś określa, że „w ten sposób utworzony został nieformalny ośrodek decyzyjny podejmowania decyzji politycznych z jednej strony, rozstrzygający najważniejsze problemy wspólnotowe, ale $\mathrm{z}$ drugiej strony, niewyrażający ich w formie prawnej” (Pietraś, 2006, s. 268-269). Uprawnienia w tym zakresie posiadała Rada. To jej decyzje miały moc prawodawczą.

Mechanizm Europejskiej Współpracy Politycznej (EWP) opierał się na zaangażowaniu instytucji, która miała podołać wyzwaniom stawianym przez państwa członkowskie wspólnot europejskich. Rada Europejska koordynowała politykę zagraniczną na szczeblu szefów państw i rządów poprzez wyznaczanie kierunków działań i określanie wytycznych dla pozostałych instytucji. Odnosiła się do całości zaangażowania państw członkowskich, w szczególności inicjując zmiany o charakterze politycznym. $\mathrm{Na}$ jej forum istniała możliwość wypracowywania wspólnego stanowiska i prezentowania go na arenie międzynarodowej. Przyjęto, iż Rada Europejska będzie spotykać się cyklicznie ${ }^{5}$. Miejscem spotkania było państwo, które w tym czasie obejmowało przewodnictwo. Drugą instytucją mającą kluczowy wpływ na kształt współpracy była Rada. W jej spotkaniach uczestniczyli ministrowie spraw zagranicznych i przedstawiciel Komisji. Rada odpowiedzialna była za realizację decyzji Rady Europejskiej. Przedstawiciel państwa, które obejmowało przewodnictwo w Radzie, pełnił także funkcję reprezentanta interesów wspólnych na arenie międzynarodowej. Funkcję tę sprawowano rotacyjnie, co pół roku, zgodnie z przyjętą kolejnością. W okresie kolejnej dekady aparat EWP poszerzał się. Państwo obejmujące przewodnictwo było organizacyjnie wspierane przez Sekretariat EWP. Komisja Europejska w ograniczonym zakresie miała wpływ na EWP poprzez uczestniczenie w obradach Rady Europejskiej i spotkaniach ministrów spraw zagranicznych.

Powstanie Rady Europejskiej zbiegło się w czasie z kilkoma wydarzeniami, które zadecydowały o realnych możliwościach podejmowania decyzji na jej forum. Kryzys polityczno-społeczny w Wielkiej Brytanii żywił się hasłami potwierdzającymi, że akcesja Wielkiej Brytanii do wspólnot przyczyniła się do pogorszenia sytuacji Brytyjczyków (Taulègne, 1993). Do tego nasiliły się tendencje separatystyczne. W lutym 1974 roku do władzy powrócił Harold Wilson, krytycznie nastawiony do EWG i wcze-

${ }^{5}$ Początkowo posiedzenia Rady Europejskiej odbywały się regularnie trzy razy do roku, raz w Brukseli, dwa razy w państwach sprawujących prezydencję w Radzie. Na wypadek szczególnych sytuacji przewidziano możliwość dodatkowych spotkań. 
śniejszego zbliżenia z Francją, a w 1976 roku zastępuje go James Callaghan, żądając od EWG zmiany warunków akcesji. W Niemczech, w maju 1974 r. Willy Brandta, który podaje się do dymisji, zastąpił Helmut Schmidt. Ministrem spraw zagranicznych zostaje Hans-Dietrich Genscher. Obaj, pomimo narastających problemów gospodarczych i fali bezrobocia, kierowani historycznym determinizmem opowiedzieli się za ściślejszą integracją. We Francji śmierć Georga Pompidou 2 kwietnia 1974 roku otworzyła erę prezydenta Valéry Giscard d'Estainga i premiera Jacquesa Chiraca, po roku zastąpionego przez Raymonda Barre. Ponownie zawiązała się nić porozumienia na linii relacji francusko-niemieckich. Jednakże entuzjazm nowego francuskiego prezydenta bazujący na idei zjednoczenia europejskiego szybko wygasł w obliczu rosnących problemów gospodarczych, wysokiej inflacji i bezrobocia. Problemy gospodarcze lat 70. oddaliły na drugi plan ideę integracji europejskiej w jej wymiarze politycznym.

Na szczycie paryskim w 1974 zapadła jeszcze jedna ważna decyzja dotycząca pogłębiania współpracy politycznej, której efektem ma być unia europejska. Léo Tindemans został poproszony o przygotowanie raportu przedstawiającego propozycje dotyczące przyszłej współpracy w tym zakresie. Przed przygotowaniem dokumentu Tindemans wstępne propozycje poddaje konsultacjom. Uczestniczyli w nich przedstawiciele instytucji europejskich, którzy przygotowali dla niego własne raporty oraz wiele osób ze świata polityki, gospodarki, związków zawodowych, środowisk reprezentujących lokalne grupy interesu dziewięciu państw. Przedstawiony przez niego raport zawierał propozycję reformy systemowej, której kształt miała nadać nowa struktura instytucjonalna. Odnosił się zarówno do sfery gospodarczej, jak i omawianej poniżej sfery politycznej. Dokument został opublikowany 29 grudnia 1975 r., a zaprezentowany Radzie Europejskiej w Luksemburgu w kwietniu 1976 roku. Jego podstawowym założeniem było stworzenie unii europejskiej. Dla realizacji tego celu Tindemans uznał za kluczową konieczność ujednolicenia systemu decyzyjnego poprzez połączenie formuły spotkań ministrów w ramach Europejskiej Współpracy Politycznej i Wspólnot, a tym samym włączenie tej współpracy do nowych ram Unii.

W raporcie Tindeman twierdził, iż „Unia Europejska nie jest końcem, ale etapem na drodze do unifikacji Europy" (Report on European Union, 1976). Zgodnie z jego propozycją w ramach współpracy politycznej państwa członkowskie zobowiązane musiałyby być do działań w oparciu o regulacje prawne, a nie tylko polityczne. Zakładał zatem prawne zobowiązania państw członkowskich w celu ustanawiania wspólnego stanowiska większością głosów. W swojej retoryce odwoływał się do sytuacji wewnętrznej w państwach EWG, twierdząc, iż „musiałem dokonać trudnego wyboru... Moje propozycje dotyczą celów i metod, które Europa może wykorzystać na rzecz zwiększenia witalności i przezwyciężenia obecnych barier" (Report on European Union, 1976). Jego celem stała się Europa mówiąca jednym głosem w polityce zagranicznej. Zmiany proponowane nie burzyły istniejącego systemu instytucjonalnego, ale go modyfikowały w celu zwiększenia efektywności. Potwierdzał to określając, że „ramy instytucjonalne są tyle warte co duch, który je wypełnia” (Report on European Union, 1976). Tindemans zwracał uwagę na stopniowe zastępowanie współpracy międzyrządowej mechanizmem wspólnotowym. W zakresie polityki zagranicznej opowiadał się za jej ścisłą koordynacją za pomocą Rady Europejskiej, która powinna wypracowywać wspólne stanowiska we wszystkich istotnych sprawach międzynaro- 
dowych, w szczególności w relacjach z rozwijającymi się państwami trzecimi. Nie przewidywał żadnej nowej struktury instytucjonalnej. Propozycja dotyczyła jedynie wzmocnienia Rady i ograniczenia możliwości dublowania jej decyzji z Radą Europejską, a także włączenia obrad ministrów spraw zagranicznych w ramy wspólnotowej Rady WE. Jego propozycje dotyczące przyszłości współpracy politycznej odnosiły się do zmian proceduralnych. Ponadto, raport stwierdzał, że w działaniach unii konieczne jest wpisanie wspólnej polityki obronnej.

Rada Europejska podjęła dyskusje o raporcie podczas spotkań w latach 1976-1977. Jako projekt zbyt postępowy nie spotkał się on jednak z aprobatą większości państw. Pomimo umiarkowanych, jak na zdeklarowanego federalistę, propozycji, opierających się głównie na pragmatyzmie wizji funkcjonowania przyszłej unii jego raport nie spotkał się z akceptacją. Rozwój Wspólnot pokazany jako stopniowy proces spotkał się z chłodnym przyjęciem. Rada Europejska dyskutowała nad raportem przy kolejnych spotkaniach. Delegacja niemiecka uznała go za konstruktywny, a Wielka Brytania i Francja za nie wpisujący się w cele krótkoterminowe podkreślając bariery, stojące na drodze do jego realizacji. Warunki gospodarcze panujące w Europie zachodniej zniechęcały do jakichkolwiek wspólnych kroków. Bezpośrednio po przedstawieniu raportu nie podjęto żadnych działań z nim związanych. Jednak do tego raportu wielokrotnie wracano, stymulował on każdą kolejną decyzję dotyczącą zmian struktury wspólnot ${ }^{6}$. Odzwierciedlenie części jego zapisów znalazło się dopiero w traktacie z Maastricht. Poboczną konsekwencją raportu był obowiązek składania przez ministrów spraw zagranicznych corocznych sprawozdań w sprawie postępów prac nad tworzeniem Unii Europejskiej.

Debacie o postępach w kształtowaniu współpracy politycznej towarzyszyły rozmowy o zaakceptowaniu regulacji o formule funkcjonowania spotkań Rady Europejskiej. Po raz pierwszy sformułowano je w Deklaracji z Londynu w czerwcu 1977. Wyrażono w niej zgodę, iż Rada Europejska powinna stanowić forum nieformalnej wymiany poglądów o charakterze szeroko zakrojonym, prowadzonym w największej prywatności, jak i stać się miejscem dla dyskusji prowadzących do podejmowania decyzji politycznych, jak i ustalania wytycznych do przyszłych działań. Spotkania miały doprowadzić do wydania publicznych oświadczeń wyrażających uzgodniony wspólny pogląd przywódców państw członkowskich. Jednakże w założeniu nie miał to być organ podejmujący decyzje prawodawcze. Uznano również, że czasami Rada Europejska będzie musiała spełniać trzecią funkcję, a mianowicie rozwiązywać problemy, które pozostają do rozstrzygnięcia, a wynikają z dyskusji podejmowanych na niższym poziomie instytucjonalnym. Postanowiono również, iż kompetencje wspólnotowe Rady Europejskiej dostosowane zostaną w przyszłości do odpowiednich ustanowionych procedur w traktatach wspólnotowych i innych umowach (The European Council, 1977). W przypadku uznania, iż Rada Europejska będzie stanowić forum nieformalnej wymiany poglądów przyjęto, iż nie będzie konieczne rozbudowane przygotowanie instytucjonalne. Szefowie rządów powinni informować się wzajemnie lub prezydencję kilka dni wcześniej o tematach, które chcą omówić. Odpowiedzialnymi

${ }^{6}$ Kolejny raport dotyczący współpracy politycznej wart odnotowania to tzw. raport trzech mędrców (B. Biesheuvel, E. Dell, R. Marjolin) powołanych przez Radę Europejską w 1978 roku. Podobnie jak wcześniejszy raport Tindemansa, nie został on przyjęty. 
za takie przygotowania zostali ministrowie spraw zagranicznych. Ich spotkania mogły poprzedzać spotkania przywódców europejskich państw. W dokumencie wskazano również, iż Rada Europejska będzie mogła opublikować swoje decyzje i wydawać oświadczenia wskazujące na opinię wspólnotową na tematy o znaczeniu międzynarodowym. W przypadku podejmowania decyzji wydawane oświadczenie miały przybrać formę pisemnej konkluzji. Oświadczenia takie nie powinny być wydawane bez wcześniejszego przygotowania (wyprzedzenie dwa do trzech tygodni). Uznano również, iż nie powinno się rejestrować nieformalnej wymiany poglądów między szefami rządów. Przyjęta została ogólna zasada, iż wymiana poglądów powinna być tak intymna, jak to tylko możliwe, a udział osób trzecich w spotkaniach ograniczany.

\section{Podsumowanie}

Rada Europejska to konglomerat interakcji państw członkowskich i innych instytucji europejskich $\mathrm{w}$ procesie kształtowania decyzji politycznych w odniesieniu do wybranych problemów wewnętrznych i międzynarodowych. W okresie 1961-1977 Rada Europejska ukształtowała swoje status quo i określiła swoje kompetencje w obliczu wieloaspektowych przemian wewnętrznej struktury instytucjonalnej Unii Europejskiej, jak i konieczności stworzenia centrum przywództwa politycznego. To instytucjonalne wzmocnienie wynikało $z$ tego iż jej międzyrządowa formuła funkcjonowania stała się niezbędnym uzupełnieniem, bądź koniecznym zastąpieniem do tej pory działających struktur. Rada Europejska stopniowo stała się głównym centrum politycznego oddziaływania, co w konsekwencji prowadziło do wyłączności w zakresie kreowania ram strategicznych w procesie realizacji polityk na arenie wewnętrznej i kreowania określonych ról organizacji na arenie międzynarodowej.

Podjęcie decyzji politycznych, a w konsekwencji przyjęcie regulacji dotyczących jej funkcjonowania, składu, a przede wszystkim stopniowe wyposażanie w określone kompetencje to elementy procesu kształtowania instytucjonalnego. To znacząco wpłynęło także na dynamikę przekształceń międzyinstytucjonalnych powiązań. Określając determinanty wpływające na te przekształcenia, podkreślić należy rosnącą funkcjonalność systemu instytucjonalnego, a także jego ograniczenia, będące, przede wszystkim, pochodną niechęci do znaczącego przyspieszania i pogłębiania procesu integracji.

Utworzona jako nieformalne forum gromadzące przywódców państw przekształciła się w zorganizowany mechanizm kształtujący polityki zewnętrzne i wewnętrzne. Jej zadania były pochodną potrzeby politycznego przywództwa i odpowiedzią na zmiany środowiska międzynarodowego. Zmiany dotyczące jej funkcjonowania odnosiły się zarówno do uwarunkowań wewnętrznych, jak i zewnętrznych. Rada Europejska kreowała rzeczywistość polityczną, wyznaczając następne etapy integracji europejskiej kolejnymi spotkaniami na szczycie. Na tych szczytach nowy mechanizm podlegał weryfikacji.

W późniejszych latach 80., Rada Europejska stała się instytucją ustalającą cele Unii we wszystkich dziedzinach jej działalności oraz, co ważniejsze, wyznaczającą drogę realizacji tych celów. To kolejny rozdział historii Rady Europejskiej, który powiązany został ze znaczącymi zmianami na scenie politycznej Francji, Niemiec i Wielkiej 
Brytanii. François Mitterand, Helmuth Kohl, Margaret Thatcher przejęli prym przywództwa nie tylko na scenie krajowej, ale także na scenie europejskiej. M. Thatcher ${ }^{7}$ wniosła misję obrony interesów narodowych, wzbudzając bodźce reformatorskie, F. Mitterand po kilku latach sprawowania funkcji przyznawał, że wielkość Francji zależy od losu wspólnot, a H. Kohl konsekwentnie prowadził politykę dialogu europejskiego. Słabość polityczna wspólnot została obnażona w kreowaniu reakcji na stan wojenny w Polsce, zamrożenie stosunków amerykańsko-radzieckich, wojnę w Afganistanie, sytuację w Iranie. W obliczu zagrożenia Rada Europejska podjęła kolejną próbę wzmocnienia współpracy politycznej.

\section{Bibliografia}

Blaes R. (1971), Le Plan Fouchet et le problème de l'Europe politique, Editions du Collège d'Europe, Bruges.

Bussière É., Willaert E. (2010), Un projet pour l'Europe, Georges Pompidou et la construction européenne, Bruxelles.

Communique de presse du Sommet de Paris, 10-11 fevrier 1961, Le dossier de l'Union politique, Recueil de documents avec préface de M. Emilio Battista, Bruxelles, Direction générale de la documentation parlementaire et de l'information, Janvier 1964, www.cvce.eu, 1.05.2012.

Communiqué final du sommet de Paris, 9 et 10 décembre 1974, „Bulletin des Communautés européennes", $\mathrm{n}^{\circ} 12$, Office des publications officielles des Communautés européennes, Décembre 1974, Luxembourg.

Czachór Z. (1994), System europejskiej wspótpracy politycznej w integrowaniu Europy, Wydawnictwo Adam Marszałek, Toruń.

Déclaration du sommet de Paris, 19 au 21 octobre 1972, Bulletin des Communautés européennes, Octobre 1972, $\mathrm{n}^{\circ} 10$, Luxembourg, Office des publications officielles des Communautés européennes, www.cvce.eu, 1.05.2012.

Déclaration sur l'identité européenne, Copenhague, 14 décembre 1973, „Bulletin des Communautés européennes", Office des publications officielles des Communautés européennes, $\mathrm{n}^{\circ} 12, \mathrm{Lu}-$ xembourg, Décembre 1973, www.cvce.eu, 1.05.2012.

Mourlon-Druol E. (2014), More than a prestigious spokesperson the role of summits and European Council in European Political Co-operation 1969-1981, w: The European Council and European Governance, red. F. Foret, Y. Rittelmeyer, London-New York.

Piers Ludlow N. (2003), An Opportunity or a Threat? The European Commission and the Hague Council of December 1969, „la Revue d'histoire de l'intégration européenne”, vol. 9, no. 2, Baden-Baden.

Pietraś Z. J. (2006), Prawo wspólnotowe i integracja europejska, Lublin.

Popowicz K. (2006), Historia integracji europejskiej, Warszawa.

Projet de traité, Plan Fouchet I, 2 novembre 1961, Recueil des documents institutionnels de la Communauté de 1950 à 1982, Parlement européen - Commission institutionnelle, Luxembourg 1982, s. 513, www.cvce.eu, 1.05.2012.

Projet de traité, Plan Fouchet II, 18 janvier 1962, Archives Nationales du Luxembourg, Coopération

${ }^{7}$ Szerzej na ten temat patrz: F. Gołembski, Brytyjskie koncepcje Unii Europejskiej, w: Unia Europejska. Nowy typ wspólnoty międzynarodowej, red. E. Haliżak, S. Parzymies, Warszawa 2002, s. 130-141; L. Jesień, Eurosceptyczna Brytania, w: Drogi do Europy, red. J. Kranz, J. Reiter, CSM, Warszawa 1998, s. 105-119. 
politique européenne. Questions fondamentales. 2e conférence des chefs de gouvernement, Luxembourg, AE 13080, www.cvce.eu, 1.05.2012.

Report on European Union, Report by Mr Leo Tindemans, „Bulletin of the European Communities”, Supplement 1/76.

Soutou G. H. (1992), 1961 le plan Fouchet, „Espoir”, nr 87, http://www.charles-de-gaulle.org/pages/ 1-homme/dossiers-thematiques/de-gaulle-et-le-monde/de-gaulle-et-lrsquoeurope/analyses/ 1961-le-plan-fouchet.php, 1.05.2012.

Taulègne B. (1993), Le Conseil européen, Paris.

Témoignage de Christian Fouchet, „Le monde”, 11 avril 1972, http://www.cvce.eu/obj/Temoignage_de_Christian_Fouchet_dans_Le_Monde_11_avril_1972-fr-349456be-b501-40ff8b1744be2ed2ba80.html.

The European Council, Conclusions of the sessions, Rome 29-30 June 1977, http://aei.pitt.edu/ 1410/1/London_june_1977.pdf.

The Rome Summit Conference, 29-30 May 1967. Communique, „Bulletin of the European Economic Community", no. 7, July 1976, Archive of European Integration http://aei.pitt.edu/1408/, 1.05.2012.

Werts J. (2008), The European Council, London.

Wessels W. (2016), The European Council, New York.

\section{Streszczenie}

Rada Europejska stopniowo przekształciła się w ośrodek podejmowania decyzji politycznych EWG, później Unii Europejskiej. Jej zakres formalnych i nieformalnych uprawnień stale się zwiększał. Kolejne postanowienia polityczne i wprowadzane prawne regulacje wyznaczały znaczące etapy tego procesu, ponieważ określały jej rolę i wiodącą funkcję w EWG. Artykuł odnosi się do źródeł i przejawów dynamiki instytucjonalnej w procesie rozwoju Rady Europejskiej w okresie 1961-1977. Jego celem jest analiza czynników warunkujących powstanie i rozwój Rady Europejskiej w świetle przyjmowanych decyzji politycznych, a także praktyki jej działań. Przedstawione w artykule zagadnienie oparte zostało na założeniu, iż ład strukturalny cechuje znacząca asymetryczność. Narastanie współzależności w kształtowanych relacjach między państwami w sytuacji potrzeby i konieczności współpracy zbiega się z procesem zmian w odniesieniu do konieczności kształtowania nowych funkcji instytucji. To znacząco wpłynęło na dynamikę międzyinstytucjonalnych przekształceń. Określając determinanty wpływające na te przekształcenia podkreślić należy funkcjonalność systemu, a także jego ograniczenia.

Słowa kluczowe: Unia Europejska, Europejska Wspólnota Gospodarcza, Rada Europejska, system instytucjonalny UE, traktat lizboński

\section{The European Council in the process of structural transformation 1961-1977}

\section{Summary}

The European Council has gradually evolved into a center of political decision making in the EEC/EU and its range of formal and informal powers continues to grow. The following political decisions and legal regulations marked a significant step in this process because it identified and acknowledged the European Council's position and its leading role within the EEC/ EU. This article examines the sources and manifestations of the institutional changes within the 
European Council in the period 1961-1977. Its purpose is to analyze the factors which influence the creation and development of the European Council in light of political decisions, Treaty's provisions and the practice of its activities. The issue discussed in the article is based on the assumption that the structural order is characterized by a significant asymmetry. The increasing interdependence in the relations between states, together with the need and the necessity of the idea of cooperation, has coincided with the process of change necessitated by the new functions of the European Council. This has significantly affected the pace of inter-institutional transformation. In defining the determinants affecting this transformation, the functionality of the system, as well as the limitations in terms of its ability should be emphasized.

Key words: European Union, European Economic Community, European Council, EU institutional system, Treaty of Lisbon 